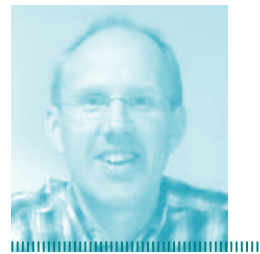

André Grundevig, leder Barnesykepleierforbundet, NSF

\title{
Palliasjon til barn
}

\author{
Palliativ behandling til barn har som mål å gi barn \\ med langvarig og dødelig sykdom best mulig livskvalitet.
}

$\mathbf{P}$ alliativ behandling og omsorg for barn, ungdom og deres familier er et felt som får lite oppmerksomhet. I Norge har vi sterke tradisjoner for palliativ behandling av kreftsyke voksne, men dette er forbundet med smertelindring. Palliasjon for barn har vokst frem som en egen gren innen faget etter 2 . verdenskrig. Dette har skjedd i kjølvannet av den enorme utviklingen innen medisinsk teknologi som har pågått de siste 30 årene. Denne utviklingen har ført til at barn med svært alvorlige sykdommer og tilstander lever lengre en tidligere. I denne artikkelen ønsker vi å belyse hva palliativ behandling og omsorg til barn er, og hva det bør inneholde.

\section{Internasjonalt samarbeid}

I mars 2006 ble det nedsatt en internasjonal arbeidsgruppe i Trento i Italia, International Meeting for Palliative Care in Children, Trento (IMPaCCT), der hensikten var å diskutere palliativ omsorg til barn i Europa. Her definerte fagfolk fra hele verden palliativ omsorg til barn, minimumsstandarder, sammenliknet palliative omsorgstjenester til barn i forskjellige land og identifiserte beste praksis. Resultatet ble et samlet styringsdokument for

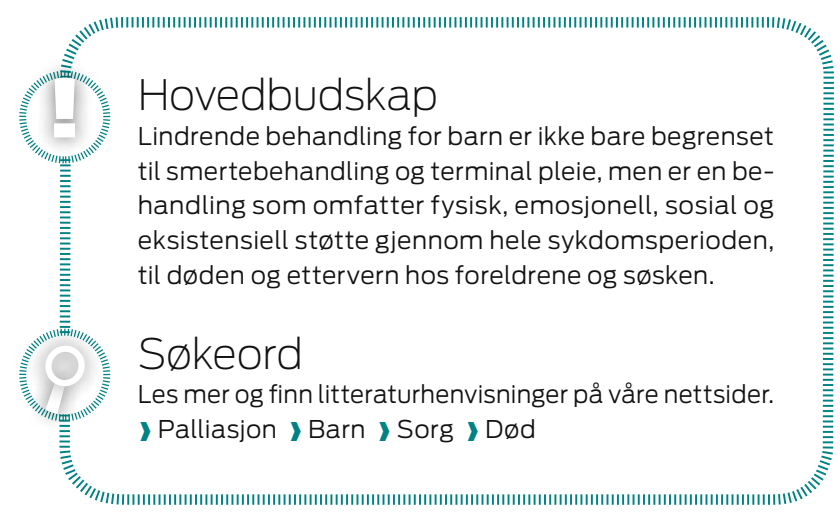

Europa med standarder for palliativ omsorg for barn med livsbegrensende - og livstruende tilstander, samt terminal sykdom. IMPaCCT og en rekke internasjonale organisasjoner anbefaler at disse standardene implementeres i alle europeiske land $(1,2,3,4)$.

\section{Definisjon av begreper}

Palliativ behandling for barn dreier seg ikke bare om symptomkontroll. I 1998 reviderte Verdens helseorganisasjon (WHO) definisjonen på palliativ behandling av barn til også å omhandle barn med andre diagnoser en kreft. Definisjonen ble også vedtatt av IMPaCCT, og disse prinsippene gjelder livsbegrensende tilstander, livstruende sykdom eller forventet forkortet levetid hos barn.

En aktiv og total tilnærming til lindrende omsorg for barn starter fra man stiller diagnosen eller anerkjenner livstruende sykdom. Den omfatter fysisk, emosjonell, sosial og åndelig støtte gjennom hele sykdomsperioden, til døden og ettervern hos foreldrene. Behandlingen fokuserer på forbedring av livskvalitet, og man kan også gi den i tillegg til kurerbar behandling. Denne type behandling og omsorg kan vare fra noen dager eller måneder til år (2).

\section{Livskvalitet}

Palliativ behandling og omsorg verken fremskynder døden eller forlenger selve dødsprosessen, men ser på døden som en del av livet. Målet er å bidra til best mulig livskvalitet i denne fasen av livet. Helsepersonell skal evaluere og lindre barnets fysiske, psykiske og sosial behov. Videre krever effektiv palliasjon for barn en bred tverrfaglig tilnærming som inkluderer hele familien. Man kan gi tilbudet i ulike deler av helsetjenesten, i barnets hjem, sykehus eller ved barnehospice. WHOs definisjon er blitt gjeldende for dette arbeidet for barn over hele verden og utgjør fundamentet for videre arbeid.
Livsbegrensende sykdom er definert som en tilstand hvor tidlig død er vanlig, for eksempel Duchenne muskeldystrofi som er en arvelig, progredierende muskelsykdom. Livstruende sykdom er definert som sykdom med høy sannsynlighet for tidlig død på grunn alvorlig sykdom, eller med mulighet for langsiktig overlevelse opp til voksen alder. Eksempler her er barn som får kreftbehandling eller intensivbehandling etter akutt skade eller sykdom.

Det er ikke slik at palliativ behandling for barn er det samme som terminal pleie. Ved palliativ behandling for barn er terminalpleien den siste delen av behandlingen som innebærer omsorg ved livets slutt. Bruken av begrepet «terminal sykdom» kan være forvirrende. Begrepet er mest brukt om alle barn med livsbegrensende sykdom, i tillegg til dem med livstruende sykdom når døden er unngåelig. Noen bruker begrepet «terminal sykdom» for å beskrive barn som er i ferd med å dø.

\section{Fire kategorier}

Basert på A Guide to the Development of Children>s Palliative Care Services (5) kan barn som skal motta palliative tjenester deles inn i fire kategorier:

1) Livstruende tilstander hvor man kan gjennomføre kurativ behandling, men hvor behandlingen kan mislykkes. Her kan tilbud om palliative tjenester være nødvendig parallelt med at man forsøker kurativ behandling og/ eller hvis behandlingen mislykkes.

2) Tilstand hvor tidlig død er uunngåelig. Og hvor det kan være lange perioder med intensiv behandling rettet mot å forlenge livet for å kunne delta i normale aktiviteter. Et eksempel er cystisk fibrose.

3) Progressive tilstander hvor det ikke eksisterer helbredende behandling. Behandlingen vil være utelukkende palliativ og kan ofte strekke 


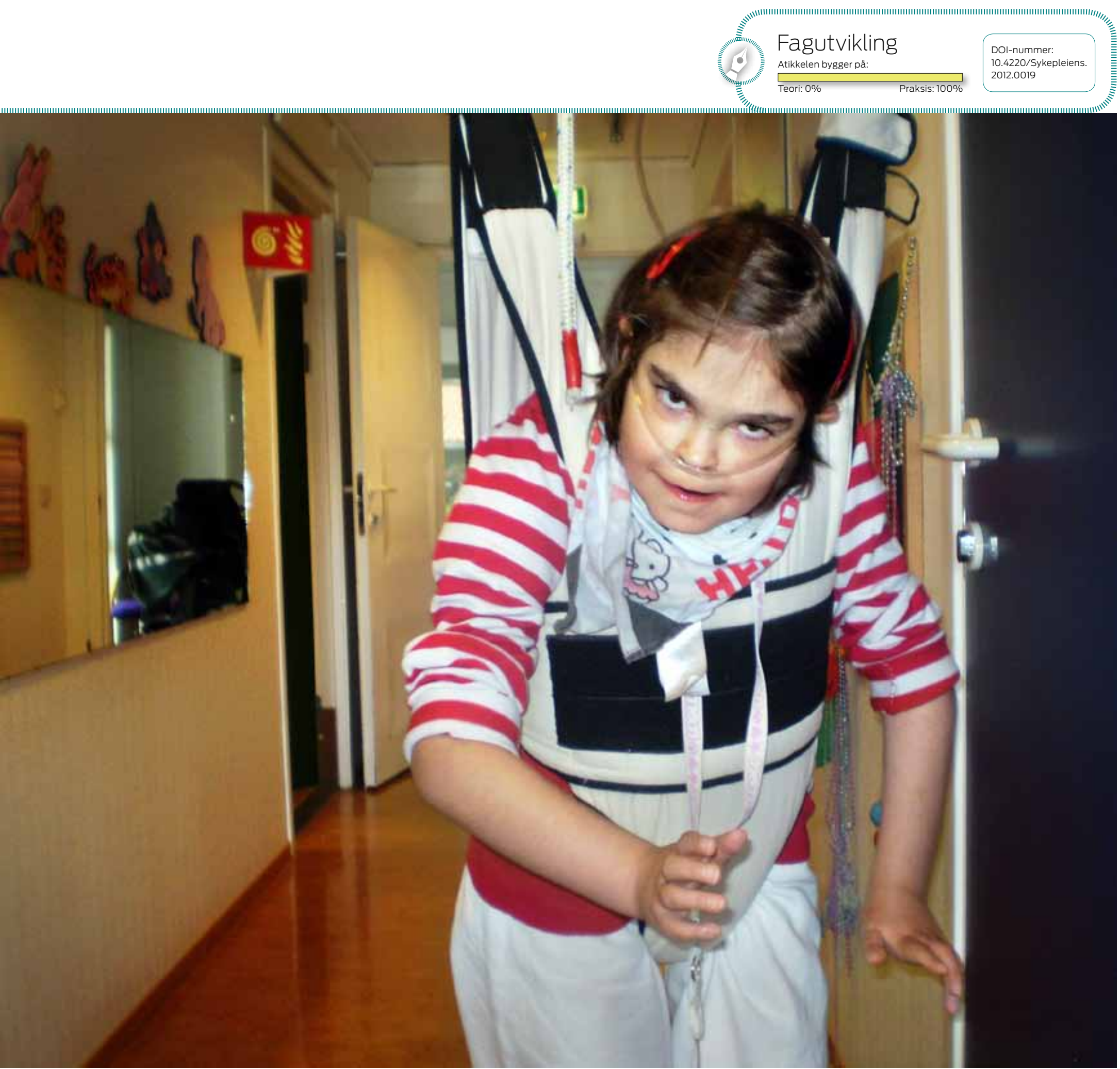

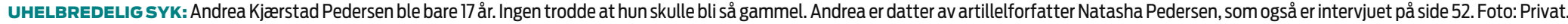

seg over mange år. Et eksempel er Battens syndrom og muskeldystrofi.

4) Irreversible men ikke-progressive tilstander med sammensatte og krevende behov for helsetjenester, der følgekomplikasjoner er sannsynlig og tidlig død kan forventes. Eksempler er alvorlig cerebral parese og multifunksjonshemming.

\section{Utfordringer}

De siste årene har det vært flere internasjonale studier som har vurdert behovet for palliativ omsorg til barn. Dette har gitt oss viktig informasjon om dødelighet, hvor disse barna døde og om spesifikke behov barn og familier, hel- sepersonell og helsetjenesten har. Ytterligere behovsanalyser er vurdert som unødvendige, fordi funnene har vært bemerkelsesverdig like.

Barn ønsker som oftest å være hjemme sammen med familien når de er syke og når de skal dø. De kommunale ressursene er derimot i stor grad utilstrekkelige for å kunne gi et slikt tilbud i dag, selv god avlastning er vanskelig å tilby disse barna og familien deres.

Videre er tjenestetilbudene ofte avhengige av hvor i landet barna bor, og hvilken diagnose de har. Det er også et betydelig forbedringspotensial når det gjelder kommunikasjon mellom de fagfolkene som er involvert i omsorgen for barn med livsbegrensende tilstander. I tillegg er det behov for økt kompetanse hos helsepersonell og andre yrkesgrupper som skal jobbe med disse barna.

\section{Organisering av tilbudet}

\section{Omsorgskoordinator}

Det bør utpekes en koordinator i det palliative omsorgsteamet for barnet. Koordinatoren skal hjelpe familien å ivareta et tilfredsstillende og hensiktsmessig støttesystem rundt barnet og familien, slik at familien sikres tilgang til praktisk støtte, sosiale, praktiske og åndelige tjenester samt avlastning. Koordinatoren vil 
fungere som det viktigste bindeleddet som gir kontinuitet, slik at omsorgen er i samsvar med behovene til barnet og familien.

Tilgang på hjelp og bistand

Ethvert barn skal ha tilgang til bistand 24 timer i døgnet, 365 dager i året, for smerter eller andre symptomer. Forespørsler må vurderes slik at barnet kan motta en hensiktsmessig behandling for å oppnå et akseptabelt nivå av livskvalitet. Hjelpen må gis på en slik måte at barnet og familien aksepterer de tiltakene som iverksettes og at tiltakene er faglig begrunnet.

\section{Avlastning}

Avlastning for familie, omsorgspersoner og barnet er viktig, enten det er for et par timer eller et par dager om gangen. Det bør være mulig å gi pusterom både i familiens hjem og borte fra hjemmet. Avlastningsbolig er ikke tenkt som mulighet her, men barnehospice
Her er det barnets dagsform som avgjør hvor aktivitets- og utdanningstilbudet skal være.

\section{Kompetansebehov}

Alle fagfolk og frivillige som arbeider med palliativ behandling og omsorg til barn bør ha nødvendig kompetanse og motta veiledning. Alle land bør utvikle en nasjonal læreplan for alle fagfolk som jobber med palliativ omsorg til barn, og man må utpeke et kompetansesenter som kan utdanne helsepersonell og andre i alle aspekter ved palliativ omsorg til barn. Et slikt kompetansesenter bør også ha ansvar for nødvendig nasjonal forskning på feltet. Det er videre viktig at man bevilger nødvendige midler for å øke kompetansen på området i alle deler av helsetjenesten.

\section{Finansiering}

Palliative tjenester bør være tilgjengelig for alle barn og familier som trenger dem, uav-

\section{«Barn ønsker som oftest å være hjemme sammen med familien når de er syke og når de skal dø.»}

med helsepersonell med spesialisert kunnskap og kompetanse på palliativ behandling.

\section{Sorg}

Sorgstøtte må starte når diagnosen stilles og fortsette gjennom sykdomsprosessen, død og ettervern så lenge det er nødvendig. Familien, pårørende og andre som er berørt av et barns sykdom og død må ha et tilgjengelig tilbud. Det er viktig at også søsken får støtte, og at dette er en integrert del av det palliative tilbudet til barn. Her bør familiens religiøse hensyn vektlegges.

Alderstilpasset omsorg

Omsorgen man tilbyr barn fra omsorgsteamet og omsorgsmiljøet skal være tilpasset barnets alder, utviklingsmessige nivå, evne til kommunikasjon og kognitive evner.

Rett til aktivitet og utdanning

Man må legge til rette for at ethvert barn skal få anledning til å delta i lek og aktivitet. Barn i skolepliktig alder har rett til undervisning tilpasset barnets utvikling og kognitive nivå. Man må legge til rette for at barnet kan gå på den skolen det sokner til, eller få tilpasset undervisning i hjemmet på dårlige dager. hengig av deres økonomiske eller helsemessige status. Staten må forplikte seg til å finansiere palliative tilbud for å gi helhetlig og tverrfaglig palliativ omsorg på en rekke arenaer, som i hjemmet, skoler, sykehus og barnehospice. Senere studier viser at palliativ behandling og omsorg for barn faktisk er økonomisk besparende og belaster i mindre grad de akutte medisinske tjenestene.

\section{Smerte- og symptombehandling}

Smerter er et vanlig symptom i palliativ omsorg, og man må alltid være på vakt for smerter, og aktivt vurdere å behandle dem. Kroniske smerter kan påvirke en persons humør, personlighet og sosiale relasjoner. I tillegg kan personer med kroniske smerter også oppleve depresjon, søvnforstyrrelser, tretthet eller kraftløshet og generell nedsatt fysisk funksjon. Derfor er det er viktig at disse barna får sine psykologiske, sosiale, åndelige og fysiske symptomer vurdert regelmessig, slik at de får riktig behandling og oppnår livskvalitet på et akseptabelt nivå. For å lykkes med dette vil tverrfaglig tilnærming og vurdering være viktig. Hensiktsmessige teknikker i forhold til kommunikasjon og samarbeid med foreldre vil være særlig viktig. Videre vil bruk av verktøy for å vurdere smerte tilpasset barn som ikke kan kommunisere verbalt og som er kognitive svekket, være viktig for å kunne hjelpe barnet. Man har utviklet slike verktøy, men disse er per i dag ikke validert i Norge. Et annet aspekt i forhold til vurdering av smerter er kulturelle forskjeller i måten å uttrykke og forholde seg til smerte på.

Unngå unødvendige smertefulle prosedyrer. Forebygg smerter i forkant av en smertefull prosedyre, både ved hjelp av medikamenter og ved bruk av ikke-medikamentelle metoder. Adekvate doser av analgetika som er ordinert til barnet som fast medikasjon, skal administreres etter klokken. I tillegg kan tilleggsanalgetika som er ordinert gis for gjennombruddsmerter. Det er viktig å vurdere administrasjonsmåten av et medikament. Det må være effektivt og gjennomførbart. En passende dose av et opiat er den dosen som lindrer smerte. Behandling med opiater leder ikke til avhengighet, men kan gi fysisk toleranse. Ikkemedikamentelle metoder bør være en integrert del av smertebehandlingen.

Behandling av den underliggende årsaken til et symptom kan være like hensiktsmessig som å gi symptomkontroll. Praktiske, kognitive, atferdsmessige, fysiske, og støttende behandlingsmetoder bør være kombinert med behandling med medikamenter. Vedvarende symptomer bør behandles med medisiner gitt med jevne intervaller. Alvorlige og ukontrollerte symptomer bør anses som et medisinsk nødstilfelle, og skal utløse tiltak som er hensiktsmessig. Bivirkninger av medisiner må forventes, og må aktivt bli behandlet.

\section{Verdig tilbud}

Det er viktig at disse barna og deres familier får et verdig tilbud. Ikke bare i helsetjenesten, men i alle deler av samfunnet. Barnesykepleierforbundet, NSF og Ja til lindrende enhet og omsorg for barn vil gjerne bidra til å utvikle et slikt tilbud, fordi dette handler om barns grunnleggende rettigheter. For å nå de målene som er nødvendige må dette arbeidet etter vårt syn og internasjonale anbefalinger, være tverrfaglig og basert på helhetlig tenkning. IIII 